\title{
Sexually transmitted diseases in clinic patients in Lagos
}

\author{
V O ROTIMI AND A O SOMORIN \\ From the Departments of Microbiology and Parasitology and Medicine, Lagos University Teaching \\ Hospital, Lagos, Nigeria
}

SUMMARY In a study of patients attending an STD referral clinic in Lagos, Nigeria, the age distribution was similar to that seen in other parts of the world and the male-to-female ratio was $1 \cdot 3: 1$. Non-specific genital infection was diagnosed in about $59 \%$ of patients and gonorrhoea in $19 \%$. Most strains of Neisseria gonorrhoeae were sensitive to penicillin (1 unit) and the six relatively penicillin-resistant strains did not produce penicillinase. Candidosis and trichomoniasis were each diagnosed in about $10 \%$ of patients and latent syphilis in $1.4 \%$ (four cases). Genital warts were also uncommon; venereophobia and other conditions accounted for $1 \%$ and $2 \cdot 2 \%$ of cases respectively.

\section{Introduction}

There is general concern at the worldwide increase in sexually transmitted diseases (STDs). A review of the global prevalence of gonorrhoea described the numbers as "of epidemic proportions." In Nigeria, as in many African countries, accurate statistics on STDs are not readily available. However, STDs, particularly gonorrhoea, are at least as common in Africa as in other parts of the world.

Lagos is the federal capital of Nigeria and has a population of about 1.5 million; it is the principal commercial and industrial centre of the country. As in western countries, casual sexual relationships with the attendant risk of STDs are common. Treatment is often unsatisfactory and complications such as urethral stricture and "watering-can" perineum are still common in Nigeria. ${ }^{2}$ There is an established aetiological association among Nigerians between hypertension and post-gonococcal urethral stricture. ${ }^{3}$ The gonococcus is an important cause of infertility or subfertility in developing countries. ${ }^{4}$

Lagos has only one specialised centre for the adequate investigation and treatment of STDs, which serves the greater part of the city and its surroundings. The acute shortage of doctors in the country forces some patients to seek treatment from private medical practitioners, often at exorbitant prices, while others consult pharmacists, native doctors, divine healers, and quacks.

Address for reprints: $\mathrm{Dr} \mathrm{V}$ O Rotimi, Department of Medical Microbiology, University of Sheffield Medical School, Beech Hill Road, Sheffield S10 2 RX

Received for publication 18 February 1979
We report our experience of STDs seen in the outpatient population attending Lagos University Teaching Hospital STD clinic over a period of 15 months from October 1976 to December 1977.

\section{Patients and methods}

\section{STUDY POPULATION}

The study population comprised 276 patients who were either referred to the STD clinic or invited to attend through contact-tracing between October 1976 and December 1977. The clinic was manned by a consultant venereologist/dermatologist, a microbiologist (trainee), a senior technician, two nursing sisters, two social workers, and one aide.

\section{CULTURAL TECHNIQUES AND SEROLOGICAL} TESTS

Urethral specimens were collected from all men who presented with urethral discharge using a sterile cotton-wool swab passed into the anterior urethra and gently rotated; the swab was plated directly on to plates of Thayer-Martin (Oxoid) and chocolate agar medium. The plates were incubated immediately in a candle jar at $37^{\circ} \mathrm{C}$ for 24 and 48 hours. Smears made from the swabs were Gram-stained and examined for intracellular Gram-negative diplococci and leucocytes. In women specimens were obtained with a swab from the cervical os and vaginal vault under direct vision with a Cusco's speculum and processed as above. A two-glass urine test was performed on the urine specimen from all men and the centrifuged deposit from each specimen showing threads or specks was examined microscopically for leucocytes, 
red blood cells, and organisms. All Gram-negative cocci growing on chocolate agar or Thayer-Martin agar were subcultured on to fresh Thayer-Martin agar and identified by the oxidase reaction and fermentation reactions in $1 \%$ sugar media. ${ }^{5}$ Isolates which were oxidase-positive and fermented glucose but not maltose or sucrose were identified as Neisseria gonorrhoeae. ${ }^{6}$

A wet preparation of the genital discharge was examined for Trichomonas vaginalis, Candida albicans, and parasites, and specimens showing yeast cells were plated on Sabouraud's agar; $C$ albicans was identified by the germ-tube test.

Serum from each patient was tested by the Venereal Disease Research Laboratory (VDRL) test and Reiter protein complement fixation test (RPCFT). Where indicated, the Frei test and the lymphogranuloma venereum complement fixation test (LGVCFT) were also performed.

Gram-stained smears from ulcers were examined for Haemophilus ducreyi.

MIC DETERMINATIONS FOR $N$ GONORRHOEAE

The six strains of $N$ gonorrhoeae isolated from the patients in Lagos that were found to be relatively resistant to penicillin (1 unit disc) were lyophilised and reidentified; the minimum inhibitory concentration (MIC) of penicillin was determined in the UK by one of us (VOR) with the following international reference strains of gonococci as controls; strains K2, V, and III (originally from Alice Reyn's laboratory).

The determination of the MIC of penicillin for the six resistant strains from Lagos was performed by method already described ${ }^{7}$ and a reference strain of Staphylococcus aureus (Oxford) was included with each batch of test strains.

\section{Penicillinase production}

Penicillinase production was detected by the chromogenic cephalosporin (nitrocefin) $\operatorname{method}^{8}$ and the starch paper technique. ${ }^{9}$

\section{Results}

\section{SEX RATIO AND AGE}

Two hundred and seventy-six patients were seen during this study; $156(57 \%)$ were men and 120 $(43 \%)$ women, a male-to-female ratio of $1 \cdot 3: 1$. Although $43 \%$ (119) of the patients were aged between 16 and 29 years (Table I), very few were in the lower part of this age range-probably because most of the young patients were treated privately.

\section{DIAGNOSES}

The most common diagnosis was non-specific genital infection (NSGI); this was made in $164(59 \cdot 4 \%)$ of
TABLE I Age distribution of clinic patients

\begin{tabular}{lcrlr}
\hline & & \multicolumn{3}{l}{ Total } \\
\cline { 4 - 5 } $\begin{array}{l}\text { Age } \\
\text { (years) }\end{array}$ & Men & Women & No & $\%$ \\
\hline $16-20$ & 8 & 3 & 11 & $4 \cdot 0$ \\
$21-24$ & 52 & 21 & 73 & $26 \cdot 4$ \\
$25-29$ & 27 & 8 & 35 & $12 \cdot 7$ \\
$30-34$ & 13 & 10 & 23 & $8 \cdot 4$ \\
$35-40$ & 6 & 15 & 21 & $7 \cdot 6$ \\
$>40$ & 4 & 16 & 20 & $7 \cdot 2$ \\
Uncertain & 46 & 47 & 93 & $33 \cdot 7$ \\
\hline
\end{tabular}

TABLE II Analysis of conditions diagnosed

\begin{tabular}{lrc}
\hline Diagnosis & No & $\%$ \\
\hline Non-specific genital infection & 164 & $59 \cdot 4$ \\
Gonorrhoea & 53 & $19 \cdot 2$ \\
Candidosis & 29 & $10 \cdot 5$ \\
Trichomoniasis & 29 & $10 \cdot 5$ \\
Lymphogranuloma venereum & 1 & $0 \cdot 36$ \\
Syphilis & 4 & $1 \cdot 4$ \\
Genital warts & 5 & $1 \cdot 8$ \\
Venereophobia & 3 & $1 \cdot 08$ \\
Others & 6 & $2 \cdot 2$ \\
\hline
\end{tabular}

the 276 patients (Table II). Gonorrhoea was diagnosed in $53(19 \cdot 2 \%)$ patients and candidosis and trichomoniasis each in $29(10 \cdot 5 \%)$.

Antitreponemal antibodies were detected in 1.4\% of patients; all were cases of latent syphilis. Venereophobia, lymphogranuloma venereum, genital warts, and a miscellaneous group of conditions accounted for the remainder of cases (Table II). More than one diagnosis was confirmed in $6.5 \%$ of patients.

\section{SOURCE OF INFECTION}

Analysis of the source of infection (Table III) showed that $34 \cdot 1 \%$ of all patients contracted infection through casual partners whom the patients had met only once and could not name or trace; regular partners and prostitutes were the source of infection in $11 \cdot 6 \%$ and $19 \cdot 2 \%$ respectively.

MIC FOR GONOCOCCAL STRAINS

Four strains of $N$ gonorrhoeae had an MIC of $0.075-0.3 \mu \mathrm{g} / \mathrm{ml}$ and two strains an MIC of $\geqslant 0.6 \mu \mathrm{g} / \mathrm{ml}$.

TABLE III Source of infection

\begin{tabular}{lrc}
\hline Source & No & $\%$ \\
\hline Regular partner & 32 & $11 \cdot 6$ \\
Casual partner & 94 & $34 \cdot 1$ \\
Prostitute & 53 & $19 \cdot 2$ \\
Spouse & 31 & $11 \cdot 2$ \\
Unknown & 66 & $23 \cdot 9$ \\
Total & 276 & $100 \cdot 0$ \\
\hline
\end{tabular}


B-LACTAMASE PRODUCTION

None of the six strains that were relatively resistant to penicillin produced $\beta$-lactamase.

\section{Discussion}

About $40 \%$ of the patients in the present study were aged between 21 and 29 years, a lower figure than the $51 \%$ recorded in Ibadan. ${ }^{10}$ This could be because our clinic was a referral clinic and the figure therefore does not give a true picture of the incidence of STD in this age group. Many young people are afraid of attending an STD clinic because of the social stigma and shame associated with STDs and also because of the long hours of waiting in the hospital. Hence many seek private treatment.

Nearly $60 \%$ of the patients in this study had NSGI, an incidence similar to that commonly reported in other parts of the world. Patients with NSGI usually presented with a slight discharge, which occasionally was profuse and purulent, together with mild dysuria and frequency in men. Non-specific urethritis, manifested by clinical evidence of urethritis without positive microbiological findings, was reported as the commonest cause of STD in men in England. ${ }^{11}$ Reports from elsewhere show that this is probably the commonest cause of STD. ${ }^{10} 12$

The figure of about $20 \%$ of gonococcal infections is similar to that found in Ibadan, ${ }^{10}$ Uganda, ${ }^{13}$ and Singapore. ${ }^{14}$ Antibiotics are freely available in Nigeria and there is no action against their indiscriminate sale, so self-medication is very common. The absence of effective legislation to control the sale of antimicrobial drugs has contributed greatly to sexual promiscuity and spread of STDs in this country. It is a popular belief among clinic patients that a capsule of tetracycline will give prophylactic cover against gonorrhoea.

The four cases of syphilis were all latent and diagnosed by positive results to serological tests in the absence of any previous history of yaws. Syphilis was also uncommon in Ibadan ${ }^{10}$ and in Kampala. ${ }^{15}$ Venereophobia was not frequently seen perhaps because the clinic was not a "walk-in" one; the three cases we did see were referred to the psychiatrist.

Four of the six isolates from Lagos had MICs of $0 \cdot 075-0 \cdot 3 \mu \mathrm{g} / \mathrm{ml}$. These were obviously strains of reduced sensitivity. The remaining two strains were markedly resistant with MICs of $>0.6 \mu \mathrm{g} / \mathrm{ml}$. Earlier reports showed that resistant strains of $N$ gonorrhoeae started to appear in $1944 .{ }^{16}$ A progressive increase in gonococcal resistance to antibiotics, especially to penicillin, has been reported. ${ }^{17} 18$ None of the six strains in this study produced $\beta$-lactamase.
A similar study in Ibadan also failed to demonstrate penicillinase production in a larger number of gonococci. ${ }^{19}$

We are grateful to Professor O Ogunbi for his encouragement and help and to Messrs S F Lawal, and I Nwabudike and $\mathrm{Dr}$ Toye Coker for their technical assistance and help. We are indebted to Professor M G McEntegart for reading through this paper and for his valued criticism. We also thank $\mathrm{Dr}$ A Hilton and Dr B I Duerden for comments on the manuscript and Mrs Hazel Bland for her secretarial assistance.

\section{References}

1. Willcox RR. A world look at venereal diseases. Med Clin North Am 1972; 56: 1057-72.

2. Osoba AO, Alausa O. Gonococcal urethral stricture and watering-can perineum. $\mathrm{Br} J$ Vener Dis 1976; 52: 387-93.

3. Elebute EA. Post-gonorrhoeal urethral stricture and hypertension in Nigeria. Tran $R$ Soc Trop Med Hyg 1966; 60: 676-80

4. Belsey MA. The epidemiology of infertility: a review with particular reference to sub-saharan Africa. Bull WHO 1976; 54: 319-41.

5. Flynn J, Waitkins SA. A serum-free medium for testing fermentation reaction in $N$ gonorrhoeae. J Clin Path 1972; 25: 525-7.

6. Cowan ST. Manual for the Identification of Medical Bacteria 2nd ed. Cambridge University Press, 1974.

7. Ericsson HM, Sherris JC. Antibiotic sensitivity testing. Report of an international collaborative study. Acta Pathol Microbiol Scand 1971; Suppl 217: 14

8. O'Callaghan $\mathrm{CH}$, Morris A, Kirky, SM, Slinger AH. Novel method for detection of $\beta$-lactamase by using a chromogenic cephalosporin substrate. Antimicrob Agents Chemother 1972; 1: 283-8.

9. Odugbemi TO, Hafiz S, McEntegart MG. Penicillinaseproducing $N$ gonorrhoeae: detection by starch paper technique. Br Med J 1977; 2: 500.

10. Sogbetun AO, Alausa KO, Osoba AO. Sexually transmitted diseases in Ibadan, Nigeria. Br J Vener Dis 1977; 53: 155-60.

11. Arya OP, Lawson JB. Sexually transmitted diseases in the tropics. Epidemiological, diagnostic, therapeutic and control aspects. Trop Doct 1977; 1: 57-66.

12. Willcox RR. Importance of the so-called other sexually transmitted diseases. Br J Vener Dis 1975; 51: 221-6.

13. Arya OP, Msanzumulure H, Tuber SR. Clinical, cultural and demographic aspects of gonorrhoea in a rural community in Uganda. Bull WHO 1973; 49: 587.

14. Rajan VS. Sexually transmitted diseases on a tropical island. $\mathbf{B r}$ $J$ Vener Dis 1978; 54: 141-3.

15. Ongom VL, Wamboka JW, Nakagwa E, Yigg A, Kamulegeya JK, Munafa C. The prevalence of venereal diseases among food- and liquor-handlers in public places in Kampala, Uganda. East Afr Med J 1976; 5 (7): 389-97.

16. Reyn A, Kosner B, Bentzon MW. Effects of penicillin, streptomycin and tetracycline on $N$ gonorrhoeae isolated in 1944 and in 1957. Br J Vener Dis 1958; 34: $277-9$.

17. Amies CR. Sensitivity of Neisseria gonorrhoeae to penicillin and other antibiotics. Br J Vener Dis 1969; 45: 216-22.

18. Willcox RR. A survey of problems in the antibiotic treatment of gonorrhoea with special reference to South East Asia. $B r J$ Vener Dis 1970; 46: 217-42.

19. Osoba AO, Montefiore DG, Sogbetun AO, Alausa KO, Anong CN. Sensitivity pattern of Neisseria gonorrhoeae to penicillin and screening for $\beta$-lactamase production in Ibadan, Nigeria. Br J Vener Dis 1977; 53: 304-7. 